\title{
AC 2009-269: HYDROGEN CURRICULUM AT MICHIGAN TECHNOLOGICAL UNIVERSITY
}

\author{
Jason Keith, Michigan Technological University \\ Jason Keith is an Associate Professor in the Department of Chemical Engineering at Michigan \\ Technological University.
}

\section{Daniel Crowl, Michigan Technological University}

Dan Crowl is the Herbert H. Dow Professor of Chemical Process Safety in the Department of Chemical Engineering at Michigan Technological University.

\section{David Caspary, Michigan Technological University}

Dave Caspary is the Manager of Laboratory Facilities in the Department of Chemical Engineering at Michigan Technological University.

\section{Jeffrey Allen, Michigan Technological University}

Jeff Allen is an Assistant Professor in the Department of Mechanical Engineering - Engineering Mechanics at Michigan Technological University.

\section{Dennis Meng, Michigan Technological University}

Dennis Meng is an Assistant Professor in the Department of Mechanical Engineering Engineering Mechanics at Michigan Technological University.

Jeff Naber, Michigan Technological University

Jeff Naber is an Associate Professor in the Department of Mechanical Engineering - Engineering Mechanics at Michigan Technological University.

\section{Abhijit Mukherjee, Michigan Technological University}

Abhijit Mukherjee is an Assistant Professor in the Department of Mechanical Engineering Engineering Mechanics at Michigan Technological University.

\section{John Lukowski, Michigan Technological University}

John Lukowski is an Associate Professor in the Department of Electrical and Computer Engineering at Michigan Technological University.

\section{Jay Meldrum, Michigan Technological University}

Jay Meldrum is Director of the Keweenaw Research Center at Michigan Technological University.

\section{Barry Solomon, Michigan Technological University}

Barry Solomon is a Professor of Geography and Environmental Policy in the Department of Social Sciences at Michigan Technological University. 


\title{
Hydrogen Curriculum at Michigan Technological University
}

\begin{abstract}
In this paper we describe curriculum development in hydrogen and fuel cells at Michigan Technological University. The cornerstone of the curriculum is the Alternative Fuels Group Enterprise, in which students can enroll in project-based courses as electives or towards the Enterprise Minor. In addition, we are developing additional materials to enhance the educational experience for chemical, mechanical, and electrical engineering students. Features of this curriculum include:
\end{abstract}

- Development of courses specifically related to hydrogen technology for undergraduate and graduate students

○ Hydrogen as an Energy Carrier: This is an introductory course that overviews traditional and alternative energy sources, with an added emphasis on generation of hydrogen for use in fuel cell applications. Hydrogen policy issues will also be addressed.

- Hydrogen Laboratory: This is a laboratory course with hydrogen safety training, hydrogen measurements, fuel cell operation and analysis, and investigation of other hydrogen-related technologies.

- Fuel Cells: There are two courses in this topic area [CM 3974 Fuel Cell Fundamentals ( 1 credit) and MEEM 4990/5990 Fuel Cell Technology (3 credits)] which introduce the basics of fuel cells and calculation of important parameters for fuel cell operation.

- Development of hydrogen technology related course material for core courses currently within the following engineering curricula (chemical engineering, mechanical engineering, and electrical engineering)

Introduction

The search for alternative energy sources is an area that has received great attention in the last few years, beginning with the January 2003 State of the Union address by President George W. Bush, approving federal funding for hydrogen fuel cell research for passenger vehicles. Similar announcements were made by state governors, most notably Michigan Governor Jennifer Granholm, stating "not only will we build these cars in Michigan, our Automotive Technology Corridor will help develop the fuel cell technology those cars will run on."

Inherent within the nation's initiative should be the development of educational programs related to fuel cells and other aspects of the hydrogen economy. Although it is common for engineering curricula to lag behind technology in emerging fields, Michigan Technological University, through their innovative Enterprise Program, has been active in introducing hydrogen technology research within the undergraduate curriculum. 
After describing the structure of the MTU enterprise program, the Alternative Fuels Group Enterprise and its projects will be presented. Following this will be a description of the elective courses and supplemental material to the traditional curriculum.

The MTU Enterprise Program

MTU students can pursue a minor or concentration (curriculum shown in Table 1 with elective modules listed in Table 2) in the Enterprise program as part of their respective accredited degree program.

\begin{tabular}{|l|l|}
\hline $\begin{array}{l}\text { Enterprise } \\
\text { Concentration } \\
\text { (12 total credits })\end{array}$ & $\begin{array}{l}\text { Enterprise Minor } \\
\text { (20 total credits) }\end{array}$ \\
\hline & $\begin{array}{l}\text { Teamwork } \\
(2 \text { credits })\end{array}$ \\
\hline $\begin{array}{l}\text { Project work } \\
(6 \text { credits })\end{array}$ & $\begin{array}{l}\text { Project work } \\
(6 \text { credits })\end{array}$ \\
\hline $\begin{array}{l}\text { Communication } \\
\text { and/or Business } \\
(3 \text { credits })\end{array}$ & $\begin{array}{l}\text { Communication } \\
(1 \text { credits })\end{array}$ \\
\cline { 2 - 2 } & $\begin{array}{l}\text { Business } \\
(5 \text { credits })\end{array}$ \\
\hline $\begin{array}{l}\text { Elective Modules } \\
(3 \text { credits })\end{array}$ & $\begin{array}{l}\text { Elective Modules } \\
(6 \text { credits })\end{array}$ \\
\hline
\end{tabular}

Table 1. Enterprise minor and concentration curriculum. Project work credits can also be used as electives for students not pursuing the minor or concentration.

CM/ENT3974 Fuel Cell Fundamentals (1)

CM/ENT3977 Fundamentals of Hydrogen as an Energy Carrier (1)

CM/ENT3978 Hydrogen Measurements Laboratory (1)

CM4310 Chemical Process Safety / Environment (3)

ENT3954 Enterprise Market Principles (1)

ENT3958 Engineering Ethics in Design and Implementation (1)

ENT3961 Enterprise Strategic Leadership (1)

ENT3964 Project Management (1)

ENT3971 Seven Habits of Effective People (1)

ENT3972 Electronic Circuit Design and Fabrication (1)

ENT3973 Geohydrologic Techniques (1)

ENT3975 Intro to Vehicle Design and System Modeling (1)

ENT3976 Personal Brand Management (1)

ENT4951 Business Plans \& Budgeting / Enterprise (1)

ENT4954 Global Competition (1)

Table 2. Partial Listing of Business, Communication and Elective Modules for MTU Enterprise Program 
A vertical (sophomores, juniors, and seniors) and horizontal (various engineering and business disciplines) integration makes the program a unique experience for students. Over $10 \%$ of students enrolled in the College of Engineering are involved in (mostly) industry-sponsored enterprise projects, in one of twenty enterprises. For further information about the MTU Enterprise Program, consult the references available in the engineering education literature ${ }^{1-6}$.

The core enterprise experience occurs in the project work courses. There is a different course number that can be correlated to the appropriate semester of the student's academic career. The courses are ENT1960 ( $2^{\text {nd }}$ Semester Freshman), ENT2950 ( $1^{\text {st }}$ Semester Sophomore), ENT2960 ( $2^{\text {nd }}$ Semester Sophomore), ENT3950 ( $1^{\text {st }}$ Semester Junior), ENT3960 ( $2^{\text {nd }}$ Semester Junior $)$ ENT4950 ( $1^{\text {st }}$ Semester Senior $)$ ENT4960 (2 $2^{\text {nd }}$ Semester Senior). All courses are one credit except for ENT4950 and ENT4960 which are two credits. Project work credits beyond the 6 listed in Table 1 are optional.

Students that are enrolled in the course attend a weekly business meeting and meet outside of class with their teammates. Each student is part of a sub-team which is assigned a group project. There are usually two or three projects each semester.

It is noted that students pursuing a Chemical Engineering undergraduate degree may use the project work courses as electives in the degree program. They are excused from one credit of the traditional curriculum, a design laboratory where the students typically work on the AIChE contest problem. The enterprise advisor typically assigns a design problem to the students who are not enrolled in this course.

It is noted that the Alternative Fuels Group Enterprise has been in existence since the fall semester of 2002. On average, there are about 25 students total enrolled in the project work courses each semester. For the fall semester of 2008, there were two projects, both related to hydrogen and fuel cells. These will now be briefly described.

- Analysis of a Hydrogen Powered John Deere e-Gator: The purpose of this semesters' project was to gain a better understanding of the electrical system of a hydrogen-powered John Deere E-Gator that was designed and constructed by students in the Alternative Fuels Group during the fall of 2007. Design requirements were provided by the enterprise advisors. Major goals of the testing included characterization of electrical flow in the system:

- Hydrogen is fed in parallel to two Ballard Nexa fuel cell units (with a maximum electrical power of $1.2 \mathrm{~kW}$ )

- Electricity from the fuel cells is combined using a battery isolator which acts as a diode to allow for load leveling and to prevent backflow into the fuel cells

- Electricity from the battery isolator flows through a deep cycle $12 \mathrm{~V}$ battery to boost the voltage to be in the proper range for the e-Gator motor controller to move the vehicle

- The circuit is closed via electrical flow back into the fuel cells. 
During the fall semester of 2008 the team finalized the experimental setup and the experiments will begin during the spring semester of 2009.

- Hydrogen Economy at Michigan Technological University: The main objective of this project is to explore the feasibility and obstacles of replacing the gasolinefueled MTU motor pool vehicles with hydrogen vehicles. Based on the ideas and principles discussed in "The Hydrogen Economy: Opportunities, Costs, Barriers, and R\&D Needs" report by the National Research Council and the National Academy of Engineering, the issues relevant to this type of conversion were discussed and weighted in order to devise a plan of action to make such a conversion possible in the future. Included in this report are assumptions that were made regarding the infrastructure, costs, production and safety and environmental issues that made this initial work possible. The intention of this work is to outline the necessary considerations for a conversion to a hydrogenfueled motor fleet for Michigan Tech.

The students found that on-site steam reforming of natural gas was the best option for this project. Due to the remote location of Michigan Tech, they did not consider any centralized hydrogen production and transmission through pipelines. They also did not consider carbon sequestration at this time.

\section{Development of Elective Courses}

With the formation of the Alternative Fuels Group Enterprise, students could take up to 8 credits of project work in the area of alternative energy. To provide students core material in one form of alternative energy, three one credit-module courses have been developed. Additionally, there is one three-credit course that students can enroll in.

It is noted that these courses are completely unrelated to the Alternative Fuels Group Enterprise. Thus, the modules are open to any student. As noted above, taking these modules count as credit towards the enterprise concentration or minor requirements. These courses will now be briefly described.

CM/ENT 3974: Fuel Cell Fundamentals. This is a one credit course designed for undergraduate students. It has been taught during fall semesters since 2004 (except for 2008). The course catalog description reads: "This course provides an introduction to fuel cells and fuel cell systems. Topics include an overview of fuel cell construction, fuel cell chemistry, fuel cell losses and efficiency, and integrating fuel cells into vehicles."

CM/ENT 3977: Fundamentals of Hydrogen as an Energy Carrier. This is a one credit course designed for undergraduate students. It will be taught during fall semesters, beginning in fall 2009. The course catalog description reads: "This course provides an overview of traditional and alternative energy sources, with particular emphasis on hydrogen energy. Discussion of energy production and sources; electric and hydrogen vehicles; production, distribution, and policy of hydrogen and the hydrogen economy." 
CM/ENT 3978: Hydrogen Measurements Laboratory. This is a one credit course designed for undergraduate students. It will be taught during spring semesters, beginning in spring 2010. The course catalog description reads: "This course provides an introduction to basic experiments and measurements that relate to hydrogen and hydrogen powered fuel cells. Includes chemical and electrical safety, fuel cell operation and introduction to fuel cell integration into practical applications."

MEEM 4990/5990: Fuel Cell Technology. This is a three credit course designed for graduate or undergraduate students. It is taught during fall semesters since 2007. The course catalog description reads: In this course, after fuel cell technology basics and operating principles, fuel cell performance will be briefly described from an energy and thermodynamic viewpoint. Major types of fuel cells are discussed. The emphasis will be on the construction features, performance behavior, and analysis. Subsequently, the balance of the fuel cell power plant, thermal system design and analysis will be discussed that affect the power generation."

\section{Module Development for Core Courses}

Another goal of this project is to develop modules for core courses in the chemical engineering, mechanical engineering, and electrical engineering curricula. To date, modules have been developed for chemical engineering courses ${ }^{7}$.

It is noted that the modules are available online at the following website ${ }^{8}$ :

http://www.chem.mtu.edu/ jmkeith/fuel_cell_curriculum/. The introductory content of each module consists of the module title, author and affiliation, core course most appropriate for the material, text reference, and key concepts. The module continues with a problem motivation and, when appropriate, a problem background. The module then has a worked out example problem and a home problem that is not worked out.

The following list summarizes the modules developed so far, arranged by core chemical engineering course, and includes a brief description of the module content.

\section{Material and Energy Balances:}

Module 1: Heat of Formation for Fuel Cell Applications

In this module, students calculate the energy content in a compressed cylinder of hydrogen, estimate the electrical energy generation, and estimate the time to operate an electronic device with a fuel cell.

Module 2: Material Balances in a Solid Oxide Fuel Cell

In this module, the principles of mass balances and reaction stoichiometry are used to estimate inlet and outlet flows of hydrogen and oxygen, and use the reaction rate to determine electric current and power in a fuel cell.

Module 3: Energy Balances in a Solid Oxide Fuel Cell

In this module, energy balances are used to determine the temperature of reactant and product streams in a fuel cell. 
Module 4: Generation of Electricity Using Recovered Hydrogen

In this module, a fuel cell is compared with the combustion of hydrogen or natural gas in a traditional power plant.

\section{Thermodynamics:}

Module 5: Equation of State for Hydrogen Fuel

In this module, the Peng-Robinson and Van der Waals nonideal equations of state are used for hydrogen to estimate the effect of high pressure on hydrogen gas density.

Module 6: Equilibrium Coefficient and Van't Hoff Equation for Fuel Cell Efficiency

In this module, students use principles of equilibrium to determine the theoretical maximum open circuit voltage and efficiency at different temperatures for a molten carbonate fuel cell. Shortcut equations are used.

Module 7: Fuel Cell Efficiency

In this module, students use principles of equilibrium to determine the theoretical maximum efficiency at different temperatures for a proton exchange membrane fuel cell and for a solid oxide fuel cell. A lengthy calculation is used. When this module is combined with Module 6, the utility of the shortcut equation for fuel cell applications is evident.

Module 8: Vapor Pressure / Humidity of Gases

In this module, the concept of vapor pressure is used to help students determine the humidity of an air / water vapor mixture in a fuel cell application. This is important since fuel cell membranes must be properly hydrated to work effectively.

Module 9: Nernst Equation

In this module, the Nernst equation (which relates the free energy of a chemical reaction to product and reactant partial pressures) is used in order to calculate the voltage in a single cell fuel cell as a function of the amount of hydrogen that is utilized.

\section{Fluid Mechanics:}

Module 10: Pressure Drop in Fuel Cell Bipolar Plate Channel

In this module, students use the mechanical energy balance and fluid mechanics fundamentals to predict the pressure drop in two different channel designs for fuel cell bipolar plate applications.

Module 11: Finite Difference Method for Flow in a Fuel Cell Bipolar Plate

In this module, students use finite difference methods to estimate the velocity at different locations within the cross-section of a fuel cell bipolar plate. This information is used to determine the average velocity, volumetric flow rate, and mass flow rate. The pressure drop is also estimated.

Heat and Mass Transfer:

Module 12: Conduction and Convection Heat Transfer

In this module, Fourier's law of heat conduction and Newton's law of cooling are used to estimate heat removal in a fuel cell stack.

Module 13: Microscopic Balances Applied to Fuel Cells

In this module, the governing differential equation for heat conduction is solved to determine the maximum temperature inside of a fuel cell stack. 
Module 14: Diffusion Coefficients for Fuel Cell Gases

In this module, the kinetic theory of gases is used to estimate the diffusion coefficient of oxygen in nitrogen, water in nitrogen, and water in oxygen.

\section{Kinetics and Reaction Engineering:}

Module 15: Tafel Equation and Fuel Cell Kinetic Losses

In this module, the fundamental behavior of the cell voltage in a fuel cell as a function of current density is discussed. Students investigate the drop in the "activation polarization" region where losses are due to reaction kinetics.

Module 16: Hydrogen Adsorption and Catalyst Surface Coverage

In this module, students use a reaction mechanism for hydrogen reaction at a fuel cell anode and perform a site balance on a platinum catalyst and use the information to determine surface coverage.

\section{Separations:}

Module 17: Hydrogen Purification

In this module, students use equilibrium adsorption isotherms to investigate a pressureswing adsorption apparatus to separate hydrogen from methane, carbon monoxide, and carbon dioxide.

Module 18: Air Separation for Coal Gasification

In this module, students use a membrane to separate oxygen from nitrogen. Having pure oxygen reduces the size of a coal gasification unit which may be used for generation of hydrogen.

Additional modules are currently under development with a final goal of approximately 25 completed. In the future, modules will be developed for core mechanical and electrical engineering courses.

\section{Project Assessment}

Course assessment has primarily been through student evaluations of teaching. As mentioned earlier, the Alternative Fuels Group Enterprise has been in existence and offered in fall and spring semesters since the fall 2002 semester. Furthermore, the course CM/ENT 3974 Fuel Cell Fundamentals has been taught every fall since the fall 2004 semester (except for fall 2008). The student evaluations are summarized in table 3 below. The student evaluations are on a scale from 1.0 to 5.0 with 5 being excellent, 4 being very good, etc.

The following list shows a sample of additional comments provided by the students on the evaluation forms:

Alternative Fuels Group Enterprise:

- "I like the hands-on activities involved in this course!"

- "You made the lecture part of this course entertaining"

- "Keep up the good work"

- "The memos organize my thoughts" 
- "I like all aspects of this course. I like the occasional speakers and the stuff we have done in the actual class."

- "I like having us write our own goals and that you allow us to lead and do things on our own."

- "You have a very positive and enthusiastic attitude about the AFG enterprise."

\begin{tabular}{|c|c|c|c|c|}
\hline Term & \multicolumn{2}{|c|}{$\begin{array}{c}\text { Alternative Fuels Group } \\
\text { Enterprise }\end{array}$} & \multicolumn{2}{c|}{$\begin{array}{c}\text { CM/ENT 3974 Fuel Cell } \\
\text { Fundamentals }\end{array}$} \\
\hline & Evaluation & \# of Students & Evaluation & \# of Students \\
\hline F02 & 5.0 & 28 & Not offered & Not offered \\
\hline S03 & 4.9 & 29 & Not offered & Not offered \\
\hline F03 & 4.9 & 48 & Not offered & Not offered \\
\hline S04 & 4.7 & 38 & Not offered & Not offered \\
\hline F04 & 4.4 & 34 & 4.7 & 20 \\
\hline S05 & 4.2 & 35 & Not offered & Not offered \\
\hline F05 & 4.3 & 23 & 4.7 & 10 \\
\hline S06 & 4.4 & 40 & Not offered & Not offered \\
\hline F06 & 4.4 & 25 & 4.8 & 21 \\
\hline S07 & 4.6 & 25 & Not offered & Not offered \\
\hline F07 & 4.9 & 16 & 4.8 & 23 \\
\hline S08 & 4.6 & 14 & Not offered & Not offered \\
\hline F08 & N/A & 12 & Not offered & Not offered \\
\hline S09 & In progress & 20 & Not offered & Not offered \\
\hline
\end{tabular}

Fuel Cell Fundamentals:

- "Interesting homework assignments and applications of the technology and sequence of topics introduced."

- "I like the 15 minutes for group homework time at the end of the lecture."

- "Keep the handouts and information like that."

During fall of 2007, the homework assignments for CM/ENT 3974 Fuel Cell Fundamentals consisted of the assignment of five modules and two problems from the fuel cell modules ${ }^{8}$.

Institutional Review Board approval was granted (MTU protocol \# M0243, Assessing New Learning Modules for Fuel Cell Instruction) to use human subjects in the classroom. A survey instrument was developed and distributed during the final class meeting. Participation in the survey was voluntary. Nineteen students participated out of an enrollment of twenty-three students. The questions on the survey and survey results, which were very positive, are summarized below.

1. I felt that the instructional material helped facilitate my learning.

$\begin{array}{ccccc}\text { Strongly Agree } & \text { Agree } & \text { Ambivalent } & \text { Disagree } & \text { Strongly Disagree } \\ 9 \text { responses } & 10 \text { responses } & 0 \text { responses } & 0 \text { responses } & 0 \text { responses }\end{array}$


2. I felt that the homework problems allowed me to apply my engineering principles to fuel cell and / or fuel cell system design.

$\begin{array}{ccccc}\text { Strongly Agree } & \text { Agree } & \text { Ambivalent } & \text { Disagree } & \text { Strongly Disagree } \\ 8 \text { responses } & 11 \text { responses } & 0 \text { responses } & 0 \text { responses } & 0 \text { responses }\end{array}$

3. Please provide any additional comments you may have on this course and/or the instructional modules:

Sample responses:

- "It was nice to see one worked out... it conceptualized and gave better background."

- "The example problems helped a lot in figuring out how to do each problem. Even when the problems weren't exactly the same as the assignment the examples were still helpful."

\section{Recommendations}

The authors will be glad to assist educators in chemical, mechanical, or electrical engineering integrate portions of this project into the curriculum. An immediate impact can be made by use of the web-based modules as they can be used in any core course. Elective courses similar to those presented here can also be implemented and may also be included in an energy-related minor or degree program.

\section{Conclusions}

This paper has illustrated course and curriculum development in hydrogen technology and hydrogen fuel cells at Michigan Technological University. The enterprise program provides a mechanism to bring real-world problems to the students. Students are free to choose their project. To aid students in their pursuit of a minor in the enterprise program, several elective courses have been developed. The fuel cell courses have been taught and have been received very well by the students. Assessment of the other hydrogen energy courses will be provided in a future manuscript.

Modules have been developed to bring fuel cell technology into the core chemical engineering curriculum. They have been developed for most core chemical engineering courses. They are available online ${ }^{8}$ and can be used by anyone worldwide.

\section{Acknowledgments}

This material is based upon work supported by the United States Department of Energy under Award No. DE-FG36-08GO18108. Any opinions, findings, and conclusions or recommendations expressed in this publication are those of the authors and do not necessarily reflect the views of the United States Department of Energy. 
JMK would also like to acknowledge partial support of the CACHE Corporation and the National Science Foundation under award DMI-0456537.

Bibliography

1. D. Stone, S. Sorby, M. Plichta, and M. Raber, "The Enterprise Program at Michigan Technological University," International Journal of Engineering Education (2003).

2. M. Plichta, M. Raber, "The Enterprise Program at Michigan Tech University: Results and Assessment to Date," ASEE Conference Proceedings (2003).

3. D. Stone, "Creating a Virtual Company and Keeping it In The Black," Proceedings of the $33^{\text {rd }}$ ASEE/IEEE Frontiers in Education Conference (2003).

4. J. Hertl, "Real-World Learning Through Student Enterprise - The Startup Phase," Proceedings of the $32^{\text {nd }}$ ASEE/IEEE Frontiers in Education Conference (2002).

5. J. M. Keith, "A Student-Driven Enterprise in Fuel Cells and Alternative Fuels," ASEE Conference Proceedings (2004).

6. J. M. Keith, M. Miller, K. Opella, J. King, J. Meldrum, C. Green, G. Gwaltney, S. Bradley, "Engineering Education in Alternative Energy," ASEE Conference Proceedings (2006).

7. J. M. Keith, H. S. Fogler, V. Thomas, D. Chmielewski, M. Gross, "CACHE Module Development for Introducing Energy Into the Chemical Engineering Curriculum: Fuel Cells," ASEE Conference Proceedings (2008).

8. Fuel Cell Curriculum Project Website, http://www.chem.mtu.edu/ jmkeith/fuel_cell_curriculum/, accessed January 2009. 